\title{
Sex Change in Islamic Jurisprudence (fiqh) UAE Law: a Juristic Analysis
}

\author{
HAMZA ABED AL-KARIM HAMMAD
}

\begin{abstract}
This study elucidates the positions of Islamic jurisprudence (fiqh) and the laws of the United Arab Emirates (UAE) on transsexuals' surgery. Using comparative analysis, the author concluded that the UAE law does not specify a rule regarding for transsexuals, but does state that in situations where the law is silent, then fiqh should be refereed to. Fiqh prohibits it; thus, the law does as well.
\end{abstract}

Keywords: • Sexual Switch • Transsexual • Reassignment Surgery

- Islamic Law • Emirati Legislation •

CorResPOndence AdDress: Hamza Abed Al-Karim Hammad, University of the United Arab Emirates, Faculty of Law, Department of Islamic Law and Studies, Al Ain, United Arab Emirates, e-mail: h.hammad@uaeu.ac.ae. 
Today's immense scientific progress has made advanced surgical operations possible, including transsexuals surgery. This surgery has spread considerably in some countries such as Iran, but is very recent in the United Arab Emirates (UAE), where the first lawsuit for transsexuals was brought 2016. Hence, the need arose to research the positions of Islamic jurisprudence ( $f i q h)$ on this matter, given that Islam is the UAE's official religion. The position of fiqh is contrasted with UAE law. Thus, this topic was examined with reference to the perspectives of medical professionals, fiqh, and UAE law.

\section{$2 \quad$ Perspectives of Medical Professional}

Transsexualism or gender identity disorder is a psychological condition and has psychological - rather than organic - causes. A person is born with typically developing sex organs and possesses both primary and secondary organs. However, starting at around three years of age, some signs appear to which parents must pay careful attention. For example, a male child may be inclined to behave according to socially conditioned behaviors of girls, preferring to play with 'feminine' toys, and dislike being treated based on his male-assigned gender. This child may believe he will grow up to become a woman. When he reaches adolescence, some feminine traits may appear in terms of his conduct and appearance. All his friendships may be with girls, whereupon he develops a strong feeling of discomfort and a lack of self-consistency (Al-Jawhari, 2019).

Some individuals undergo transsexuals, whether from male to female or vice versa. In the first situation, the penis is removed and reconstructed into a vagina (i.e., castration), and the breasts are enlarged. In the second scenario, the breasts are removed and a penis is constructed. The vaginal canal is closed to varying degrees, along with psychiatric and hormonal treatment (Nagai et. al., 2005: 233; Kline \& Schrock, 2015: 39).

\section{$3 \quad$ Perpectives of Fiqh}

Many modern Muslim scholars such as Mohammad Al-Shanqiti, Mohammad Bushiah, and, Mohammad Mansour, have issued fatwas prohibiting transsexuals surgery, and the Islamic Fiqh Academy has determined that non-intersex individuals may not receive it. In such a situation, any attempt to change the body is a crime, and the perpetrator deserves to be punished. This stance relies on a set of religious statements, such as the following ayahs (verses from the Qur'an, the holy text of Muslims): 
"And he, Shaitan [Satan] said: I will take an appointed portion of your slaves (119). Verily, I will mislead them, and surely, I will arouse in them false desires; and certainly, I will order them to slit the ears of cattle, and indeed I will order them to change the nature created by Allah.' ... whoever takes Shaitan as a walee[protector or helper] instead of Allah, has surely suffered a manifest loss.(Qur'an4: 119-120)."

The ayahs above clearly indicate that altering the human body is seen as modifying a holy creation; hence, such an activity is believed to be the work of Satan. Satan tricks humans into changing creation; by acting according to Satan's ways, humans object to what God has willed by transforming an individual's sex without there being a medical need. In this context, altering creation is represented by the physician either removing the penis and testicles, in the case of a male-to-female transition, or removing the breasts and closing up the vaginal canal for a female to male transition(Al-Shanqiti, 1994: 200; Hasmady, 2018: 51). According to fiqh, there is no justification for transsexuals surgery in this scenario.

The Hadith confirm these ayahs in light of what the Prophet Muhammad said pertaining to the damnation of those that modify God's creations (Muslim, 2000: 949). According to Islamic jurisprudence, a person becomes damned when he or she carries out a religiously prohibited action. If it were allowable, then those committing it would not be characterized as damned.

There are various reasons for this, most of which can be traced to infancy and early childhood. A poor upbringing can also be a factor. If a man or woman does not fulfill cultural gender roles, marry a member of the opposite sex, and have children according to the manner in which it is believed that God created him/her, then he/she is seen as eschewing his/her 'natural' sex. From the angle of Islamic jurisprudence, there is no doubt that transsexuals surgery constitutes opposition to the will of God, insofar as determining a person's gender is concerned (Tahboub, 1987: 424).

According to fiqh, transsexuals surgery can also cause physical, psychological and social damage. Causing harm is religiously prohibited. For example, it is believed that altering the human body will lead non-sex organs to malfunction, especially since the reproductive organs differ between males and females, and due to the use of hormones and medications administered to the person prior to and after SRS. In terms of psychological detriment, it is thought that surgery will negatively impact the person's habits and behaviors. Such an occurrence will not materialize rapidly, but rather in the wake of disturbances and 
contradictions given the discrepancy between the gender the person is assigned at birth, and the gender he/she chooses to live as (Bushiah, 2004: 489-490).

Regarding social harm, from the angle of fiqh, transsexuals surgery - if increasingly permitted - would produce chaos in society. This would manifest in official registers and documents (for example, birth records)insofar as names, professions, and associated matters are concerned. It is not only the transgender individual's life that is affected by transsexuals surgery but also the lives of his/her relatives (Bushiah, 2004: 489-490).

A small number of modern scholars such as Mohammad Malawi, have declared that it is permissible for a transsexual to undergo transsexuals surgery on the grounds that transsexuality is a pathology requiring surgical treatment. Islamic law urges encourages treating ailments, especially since letting the patient continue to live as the gender with which he/she does not identify might lead him/her to become suicidal. Preserving life is among the foremost aims of Shariah. In this case, treatment is a necessity, and the Islamic principle is that necessity makes prohibited actions allowable (Al-Mawlawi, 2017).

The proponents of this opinion placed two restrictions on allowing transsexuals surgery:

(1) The patient shall exert substantial effort to adapt to his/her physical condition, as his/her sense of being transgender might be an illusion, whereby a psychological schism is produced between his/her inner feelings and outer physical appearance.

(2) The physician shall strive to employ all the methods and tools of modern psychiatry to treat the patient as a psychologically ill individual for a period of at least two years (Al-Mawlawi, 2017).

\subsection{The Author's Opinion on this Matter}

The author deduces that it is reasonable to prohibit Transsexualism the verse mentioned earlier and the hadith pertaining to the damnation of those that modify God's creations. The author critiques the assertions presented by the advocates of the second opinion, by stating that relying on the religious principle 'necessities allow prohibited actions' entails a set of conditions upon application. These criteria include the risk of death or fear that the organs will fail. In terms of transsexuals, some specialists such as Amin Al-Jawhari and Majed Tahboub, believe that being transgender is a psychological illness, rather than an organic state, and does not necessarily entail death or organ failure. 
In contrast, proponents such as Mohammad Malawi, of transsexuals surgery have grounded their stance in the belief that being transgender is an illness and that Shariah urges treatment. The author maintains that this rule is valid. However, based on the reasoning that being transgender is a psychological disorder, the problem lies in the application of the abovementioned rule, since such a disorder could be treated with nonsurgical techniques.

\section{The Perspectives of UAE Law}

In response to medical advancements, the UAE passed Federal Decree, Law No. 4 of 2016, a regulation related to medical responsibility. This legislation is considered to be a qualitative leap in the Middle East, given that the UAE is only the second state in the Gulf (besides Iran) to allow SRS Based on the fatwa of Ayatollah Khomeini, the leader of the Iranian Republic in 1980 (Tolino, 2017: 230; Fanack, 2016).

The law differentiates between a sex change and a sex reassignment. Article 1 stipulates that 'sex change' refers to altering the sex of a person whose sexual affiliation is clear in terms of masculinity or femininity. His/her sexual physical features are congruent with his/her physiological, biological and genetic characteristics, and there is no doubt concerning his/her sexual affiliation as male or female. As for sex reassignment, Article 1 main taints that it is permissible to carry out medical interventions that aim to reassign the sex of a person whose sexual affiliation is ambiguous. In such a case, there is doubt concerning whether he/she is considered male or female, such that he/she has physical traits that diverge from his/her physiological, biological or genetic characteristics. For example, an individual may appear male based on physical appearance alone, but in reality, that person is seen - and identifies as - female.

Article 7 permits SRS and places a set of restrictions on it. For instance, a person must have an ambiguous sexual affiliation, as well as sex characteristics that do not match his/her physiological, biological or genetic features. This must be established through medical reports and approval from a specialized medical committee created by a health department, with a view to determining the patient's sex and authorizing SRS. The committee has an obligation to refer the matter to a psychiatrist to effectuate the necessary psychological preparations. 


\subsection{Cases of Sex Changes in UAE Courts}

On September 28, 2016, a first case ' young woman A' was brought to the UAE court regarding a sex change. The petitioner, a young woman represented by the attorney Ali Abdullah Al-Mansouri, asserted that since the age of five she had played with boys, preferred wearing their clothes, and had not identified as female. Instead, she claimed that she felt male from an emotional standpoint, and preferred being referred to with male pronouns. She expressed same-sex attraction. Al-Mansouri emphasized that his client adhered to her medical, religious, and legal rights, represented in performing SRS.

The plaintiff was subject to a complete medical examination performed by several expert medical committees. This was necessary to prove that she suffered from pathology. The committees found that she suffered from gender identity disorder. She constantly felt and was convinced - that she was male, a sentiment she had recognized continuously since childhood and after puberty.

Al-Mansouri referred to Federal Decree, Law No. 4 of 2016 concerning medical responsibility, whereby SRS is allowed when a person's sexual affiliation is vague, or when an individual has sex characteristics that do not coincide with his/her physiological, biological or genetic traits. Al-Mansouri argued that his client suffered from a disorder that had caused her brain to become 'male' - in opposition to the gender she was assigned at birth. Hence, the law permitted her to receive SRS. Al-Mansouri also demonstrated that all of the medical reports issued concerning his client recommended that SRS be expedited; however, currently, performing SRS continues to depend on receiving permission in a court of law (Jamal 2016; Al'amir, 2016).

The Abu Dhabi Federal Court of First Instance decided to postpone the lawsuit based on the wishes of the attorney of government cases, who requested time to study the plaintiff's memorandum. On December 27, 2016 the Abu Dhabi Federal Court of First Instance decided to appoint a five-member committee of experts in psychiatry, genetics, urinary tract surgery, gynecology, and forensic medicine. The committee was to investigate the plaintiff's claims, the defenses raised by the defendants, other relevant documents, the necessary tests needed to examine the plaintiff, and her medical reports. The overall goal was to reveal her motives and establish the need for SRS - or lack thereof. The committee also had to determine whether the plaintiff suffered from gender identity disorder in accordance with medical reports supporting the need for SRS, and whether she should receive any treatments and medicine to remedy the ailment (Al'amir, 2016). 


$$
\begin{aligned}
& \text { Medicine, LAw \& SOCIETY } \\
& \text { H. Abed Al-Karim Hammad: }
\end{aligned}
$$

Sex Change in Islamic Jurisprudence (fiqh) UAE Law: a Juristic Analysis

\subsection{Judicial Precedent in the UAE}

In another case, two young women from the UAE aged 26 and 28 underwent hormonal, behavioral, and surgical treatment to become male in a European country. Afterward, they brought legal action at the Abu Dhabi Federal Court of First Instance. They demanded that their names be legally changed. This is considered the first precedent 'case of $(\mathrm{H}, \mathrm{Y})^{\prime}$ for SRS in the UAE. To date, the first case woman still has not undergone SRS, and is awaiting the court's decision. The second woman received SRS. These two women expressed that that they were motivated to pursue SRS after seeking advice from several expert medical committees. After the two women were examined, the committees issued reports that supported the need for SRS (Al-Mawlawi, 2017).

This case concluded on January 23, 2018. The court rejected requests to allow the plaintiffs to change their names in government registries and documents. Al-Mansouri attributed this outcome to the fact that the committees acknowledged his clients would not return to being female, and that they had made a complete sex change. Concurrently, the committees explained that rejecting their lawsuit presented a risk to their lives, because if they remained in female bodies with their documents, which confirm them as female, this would lead them to become depressed. In turn, they might commit suicide. Al-Mansouri stated that the committees stressed the need to entrust committee composed of members who are experts in gender dysphasia, and for the physicians to have knowledge of it; this is established in the reports.

The advocate submitted a memorandum in which he argued that the decision erred in applying the law. He relied on the report of the expert, without examining the substantive defenses of the appealers. This may have altered the position. Al-Mansouri declared that the expert's report was deficient and did not illustrate the true facts, given that it did not examine the psychological state of the appealers. Al-Mansouri argued that the report merely described the appealers 'physical appearance as females; it only contained an external analysis, without studying the case in an expansive manner. The report did not address the true matter: that the appealers had suffered from gender identity disorder since an early age, and cannot adapt to their situation given that they are males imprisoned in female bodies; hence, this impacted their psychological condition (Al'amir, 2016). Ultimately, there was an appeal of the decision via the request to form a medical with knowledge of gender identity disorder. This had not been available in the previously formed psychiatric committee, which in turn affected the report, rendering it useless as there was an absence of expert son the ailment. Instead, there were only ordinary psychiatrists (Mohammad, 2018). 


\section{$5 \quad$ Comparisons and Corrections}

By reading about the positions of UAE law, the author found that it does not expressly state a rule on sex change. However, even though it does not provide an explicit stipulation, sex changes have been criminalized based on the premise that they are prohibited according to Shariah. Furthermore, Article 7 of the UAE's Constitution declares Islam as the country's official religion, and Sharia is the main source of legislation. In addition, the UAE's civil code determines what constitutes the legal umbrella of UAE laws. According to Article 6,in case a judge does not find a provision in a law, he shall issue a ruling based on Shariah.

The position adopted by the author is emphasized by Fatwa 10560, issued by IACAD. This fatwa states that it is prohibited for a person to alter his/her body from male to female or vice versa (IACAD, 2015b). IACAD released another fatwa in response to the question: 'To what extent is it permissible for a person who experiences severe gender dysphasia and feels female - but has male genitalia - to change from male to female by employing surgical procedures? 'The answer was clear: It is not allowable to change one's sex unless a person appears to have both male and female sex organs, one of them being stronger than the other in terms of function (insofar as toilet functions).It is up to expert physicians to determine whether that person is male or female.

Regarding an individual with male sex characteristics who identifies as a woman, Fatwa 8616views him shaving a psychological disorder resulting from upbringing, environment, and culture. In such a scenario, SRS is not allowed. The individual is contradicting his innate nature in terms of masculinity and femininity. He must receive treatment, and must spend time with righteous people who affirm his innate nature, the characteristics of manliness and benevolence, and who save him from intellectual, emotional, and cultural deviation (IACAD, 2015b).

Concerning cases that are still pending and being considered by UAE courts, the author believes that these require medical reports. The goal is to determine whether an individual is suffering from an intersex condition, for which it is permissible to reassign sex in conformity with the restrictions adopted by the law, or whether the individuals transsexual, for which sex change is not allowed. 
In addition, the author points out that Islamic jurisprudence does not specify the punishment for a transsexual person who undergoes SRS, nor for a physician who performs SRS, as the law does not clearly stipulate a penalty for violating the conditions stated in Article of the UAE Medical Liability Act 2016 7. However, the question remains whether UAE citizens who travel abroad and receive SRS should face punishment upon return to their home country, and whether a sex change should be reflected in their official documents. The researcher does not have an answer of these questions, so we need a clear answer from UAE Judicial Authority of these questions.

\section{Conclusion}

This paper elucidates the positions of fiqh and UAE Law on transsexuals. The author used comparative analysis and concluded that the UAE law does not specify a rule regarding SRS for transsexuals, but does state that in situations where the law is silent, then figh should be refereed to. Figh prohibits SRS; thus, the law does as well. This is supported by the fatwas issued by IACAD.

\section{References}

Al'amir, T. (2016) جدل حول أول قضية تصحيح جنس بالدولة (Controversy on the first case of sex reassignment in the state), Alittihad.ae (September 26, 2016), retrived from: https://www.alittihad.ae/article/46398/2016/\%D8\%AC\%D8\%AF\%D9\%84-

\%D8\%AD\%D9\%88\%D9\%84-\%D8\%A3\%D9\%88\%D9\%84-

$\% \mathrm{D} \% \% 82 \% \mathrm{D} 8 \% \mathrm{~B} 6 \% \mathrm{D} 9 \% 8 \mathrm{~A} \% \mathrm{D} 8 \% \mathrm{~A} 9-$

\%D8\%AA\%D8\%B5\%D8\%AD\%D9\%8A\%D8\%AD-\%D8\%AC\%D9\%86\%D8\%B3-

\%D8\%A8\%D8\%A7\%D9\%84\%D8\%AF\%D9\%88\%D9\%84\%D8\%A9 (January 15, 2019).

Al-Jawhari, A. جدل حول أول قضية تصحيح جنس بالدولة (2016), (Controversy on the first case of sex reassignment in the state), Fujairahtodayae (Sep 26, 2016), retrieved from: https://fujairahtoday.ae/2016/09/26/38860 (January 15, 2019).

Al-Mawlawi, F. فتوى تغيير الجنس (Fatwa published in Bahraini Al-Watan newspaper), Alwatannews.net (January 13, 2017), retrieved from: https://alwatannews.net/article/150310/Varieties/\%D9\%85\%D8\%B1\%D9\%8A\%D8\%B6$\% \mathrm{D} 9 \% 84-\% \mathrm{D} 8 \% \mathrm{~A} 7 \% \mathrm{D} 9 \% 84 \% \mathrm{D} 9 \% 88 \% \mathrm{D} 8 \% \mathrm{~B} 7 \% \mathrm{D} 9 \% 86-$

$\%$ D8\%B9\%D8\%B4\%D8\%AA-\%D8\%B1\%D8\%AC\%D9\%84\%D8\%A7-

$\% \mathrm{D} 8 \% \mathrm{~A} 8 \% \mathrm{D} 8 \% \mathrm{AC} \% \mathrm{D} 8 \% \mathrm{~B} 3 \% \mathrm{D} 8 \% \mathrm{AF}-$

$\% \mathrm{D} 8 \% \mathrm{~A} 7 \% \mathrm{D} 9 \% 85 \% \mathrm{D} 8 \% \mathrm{~B} 1 \% \mathrm{D} 8 \% \mathrm{~A} 3 \% \mathrm{D} 8 \% \mathrm{~A} 9-$

\%D9\%88\%D8\%A3\%D9\%86\%D8\%A7-\%D9\%84\%D8\%B3\%D8\%AA-

\%D8\%A8\%D9\%88\%D9\%8A\%D8\%A9 (February 4, 2017).

Al-Shanqiti, M. أحكام الجراحة الطبية والآثار المثرتبة عليها (Rules of medical surgery and its consequences) (Jeddah: AlSahabah Library).

Bushiah, M. جر احات الذكورة والأنوثة في ضوء الطب والفقه الإسلامي(2004) (Masculinity and femininity surgeries in light of medicine and Islamicfiqh) (Egypt: Dar Al-Falah). 
Fanack تغيير الجنس في إيران (2016) (Change of sex in Iran), Fanack.com (November 29, 2016), retrived from: https://fanack.com/ar/iran/human-rights/gender-reassignment-in-iran (April 11, 2019).

Hasmady, F. حكم تحويل الجنس: در اسة تقويمية في ضو مقاصد الشريعة (The Rule of Sex Change: An Evaluative Study in Light of the Maqāșid al-Sharī'ah), International Journal of Fiqh and Usul al-Fiqh Studies, 2(2), pp. 50-59.

IACAD (2015a) تغيير الجنس ومخالطة من يفعل ذللك (Fatwa10560: Sex Change), services.iacad.gov.ae (November 29, 2012), retrieved from: https://services.iacad.gov.ae/SmartPortal/fatwa/PublishedFatwa/Details/10560, Published: Nov 29, 2012 (January10, 2019).

IACAD (2015b) حكم تغيير الجنس من ذكر لأنثى أو العكس لتغلب الشعور بأحدهما دون الآخر (Fatwa8616: Rule on the sexual change from male to female or the opposite dueto the dominance of one over the other), services.iacad.gov.ae (December 25, 2012), retrieved from: https://services.iacad.gov.ae/SmartPortal/fatwa/PublishedFatwa/Details/8616 (January 10, 2019).

Ibn Majah, M. Y. سنن ابن ماجة (2009) ستأ (Sunan Ibn Majah) (Beirut: Dar Al-Risalah).

Jamal, A. تعرّف على جديد قضية فتاة "التحول الجنسي (2016) (The case of the sex change woman), emaratalyoum.com (September 28, 2016), retrived from: https://www.emaratalyoum.com/local-section/accidents/2016-09-28-1.932643 (February 2, 2017).

Kline, C. \& Schrock, D. (2015) What is gender reassignment surgery? A medicalassessment with a biblical appraisal, Journal for Biblical Manhood \& Womanhood, 20(1), Spring, pp. 3547.

Mansour, M. K. الأحكام الطبية المتعلقة بالنساء في الفقه الإسلامي (1999) (Medical rules related to women in Islamic jurisprudence) (Amman: Dar El Nafaes).

Mohammad, M. (2018) Appeal of the case of sex change, albayan.ae (March 21, 2018) retrieved from: https://www.albayan.ae/across-the-uae/accidents/2018-03-21-1.3215466 (January 15, 2019).

Muslim, Bin Al-Hajjaj (2000) صحيح مسلم (Sahih Muslim) (Al-Riyadh: Dar Al-Salam).

Nagai, A., Eijiro, T., Yuzaburo, N. \& Tetsuya, T. (2005) Sex reassignment surgery for male to female transsexuals: initial experience at Okayama University Hospital, Acta Medica Okayama, 59(5), pp. 231-233.

Tahboub, M. جر احة التجميل بين المفهوم الطبي و الممارسة (Cosmetic surgery between medical concepts and practices) Kuwait: Conference Islamic vision of some medical practices.

Tolino, S. (2017) Transgenderism, Transsexuality and SexReassignment Surgery in Contemporary Sunni Fatwas, Journal of Arabic and Islamic Studies, 17, pp. 223-246, doi: 10.5617/jais.6116. 